\title{
Becoming a Mindful Superintendent in a "Turnaround" District
}

\author{
Nancy Coogan'1, Gordon Gates ${ }^{2}$, Teena McDonald ${ }^{2}$ \\ ${ }^{1}$ Tukwila School District, Tukwila, USA \\ ${ }^{2}$ Department of Educational Leadership, Sport Studies, and Educational/Counseling Psychology, Washington \\ State University, Spokane, USA \\ Email: coogann@tukwila.wednet.edu, gates@wsu.edu, tpmcdonald@wsu.edu
}

Received 24 August 2015; accepted 20 September 2015; published 23 September 2015

Copyright (C) 2015 by authors and Scientific Research Publishing Inc.

This work is licensed under the Creative Commons Attribution International License (CC BY). http://creativecommons.org/licenses/by/4.0/

(c) (i) Open Access

\section{Abstract}

Superintendents face numerous challenges navigating the turbulence within districts created by employee turnover that follows implementation of turnaround policies. Literature on educational policy, the superintendency, and resilience calls for researchers to examine how mindfulness supports leadership for improving instructional services to increase student achievement while balancing multiple problems that attend heightened instability and decreased satisfaction of school personnel. Over a two-year period of study, observations, interviews, and artifacts were gathered and analyzed to describe the experience of a new superintendent who led the turnaround process in a small urban district. Balancing the various demands that attend leading a turnaround district is no small feat and includes responsibilities related to: building relationships with the school board, district staff, and community; hiring and firing of cabinet members, campus level administrators, and teachers; revamping instructional and evaluation practices, while seeking to build trust with stakeholders; bringing predictability and voice in district governance. High stakes accountability may be a tool for change, but it is mindfully serving students and families that nurtures resilience.

\section{Keywords}

Superintendency, Turnaround Leadership, Resilience, Mindfulness

\section{Introduction}

The removal of poorly performing personnel from low achieving schools is an underlying purpose and principle of recent educational policies (Kutash et al., 2010; Ravitch, 2010). Although schools deemed as failing are the 
target of current federal legislation (i.e., Race to the Top), rising turnover of teachers and administrators is evident across all schools (Aud et al., 2011). Scholars describe accountability mandates as contributing to increased demands, reduced job satisfaction, and decreased retention of educational professionals (Bellingrath, Weigl, \& Kudielka, 2009; Conley \& You, 2009; Klusmann et al., 2008; Philipp \& Schupbach, 2010). Recognizing the deleterious impact on student learning from teacher dissatisfaction and turnover, advocates of educational reform call for inquiry about ways to mitigate these pitfalls (Murphy, 2009). Elsewhere, Murphy \& Meyers (2009) invite researchers to investigate and make recommendations concerned with policy and practice refinement. Limited and contradictory findings from research on the efficacy of turnover strategies in both education (e.g., Malen \& Rice, 2004) and organizational studies (e.g., Messersmith, Lee, Guthrie, \& Ji, 2014) also support the need for further examination of how turnover is perceived and experienced by school personnel.

Concern over the emotional and physical toll of school reform on the well-being of educators is not limited to the turnaround literature. Recent research on educational administrators finds high levels of reported stress and growing alarm over the negative impact of such distress on the health of individuals, as well as the long-term ramifications to the profession for keeping and attracting qualified candidates for positions of building and district leadership (Glass \& Franceschini, 2007). In particular, superintendents charged with leading districts through reform efforts and sanctions face numerous challenges navigating the turbulence created by revision of local policies, procedures, and practices (Hawkins \& Martin, 2011). The test of leadership centers on improving instructional services to strengthen student achievement while balancing multiple problems that attend heightened instability and decreased satisfaction of school personnel. The work of instituting student supports, modifying teaching methods, and updating curriculum is no small feat, particularly in small urban districts (Sherman, 2007). It is worth noting that urban schools enroll a disproportionate percentage of students from low socioeconomic backgrounds, as well as those of linguistic and ethnic diversity, which add to the urgency and complexity of decision making and action concerned with teaching and learning (Gardiner \& Enomoto, 2006; Riehl, 2000; Theoharis, 2008). In addition, urban schools are found least likely to demonstrate high performance and most likely to evidence little improvement compared to their suburban peers (Price, 2010; Rodriquez, Murakami-Ramalho, \& Ruff, 2009; Sicoly, 2002). Berkovich \& Eyai (2015) summarize the leadership literature to suggest pursuing socially just policies and procedures for traditionally underserved students as rewarding for principals and superintendents. Yet, they also note that "encounters with social injustice, community resistance to leader-initiated equalizing interventions, and failures in such efforts are all associated with leaders' negative emotions" and conclude that "educational contexts characterized by overwhelming social injustices sometimes lead to leaders' development of resilience, which may be helpful in the short term but may contribute to emotional fatigue in the long term" (p. 142). Berkovich and Eyai direct researchers to investigate how educational leaders develop resilience and provide recommendations for leadership practice.

Interest in resilience, both as a psychological and organizational attribute, is recent and growing (Windle, Bennett, \& Noyes, 2011). Windle et al. define resilience as "the process of negotiating, managing and adapting to significant sources of stress or trauma" (p. 2). Perhaps explaining some of the attention being given resilience are findings that argue resilient individuals and organizations are better able to cope with unexpected events, absorb change, sustain shock, and bounce back from disruptions (Kendra \& Wachtendor, 2003; Weick \& Sutcliffe, 2007; Wildavsky, 1991). The literature presents various and conflicting theories that draw from multiple disciplines to explain resilience, since space limitation precludes the review here. Instead, it is sufficient to share Rees, Breen, Cusack, \& Hegney's (2015) analysis of literature that claims "Increasingly, studies are proposing that mindfulness is an important characteristic of a resilient individual" (p. 74) and forwards invitation to investigate ways mindfulness may assist those facing difficult circumstances continue not only in carrying-on but thriving.

In summary, literature pertaining to educational policy, the superintendency, and resilience point to the value of research focused on understanding mindfulness as part of educational leadership practice. The purpose of this study was to describe and analyze the perspective of a new superintendent as she led the turnaround process within a small urban district in the Pacific Northwest. The paper proceeds by articulating the conceptual framework on mindfulness we used for gathering and analyzing data. Next, the action research methods followed in conducting the study are provided. The section on findings offers description of several incidents revealing how resilience was nurtured through intentional attention to being present. The paper concludes with a discussion and summary of key implications. 


\section{Conceptual Framework}

The notion of mindful cognition and action informing our study draws on theory concerned with being more fully present including attention to the examination of experience through various perspectives and maintaining mental functioning that is continuously updated in order to deepen appreciation of what may be added to perception (Burpee \& Langer, 2005; Carson \& Langer, 2006; Langer, 1993; Weick \& Sutcliffe, 2007). Mindfulness allows for inquiry, interpretation, and action. It is "a persistent mindset that admits the possibility that any "familiar' event is known imperfectly and is capable of novelty" (Weick, Sutcliffe, \& Obstfeld, 1999: p. 88). Mindfulness is deliberately attending and reflecting in order to deepen one's understanding of the perspective of others. It is not a passive experience but an active examination of the present (Woods, 2009).

Mindfulness focuses on the importance of authenticity, self-acceptance, and noticing complacency. Complacency occurs in organizations as routines become fixed or set through daily practice. Individuals who practice mindfulness are not only present in the moment, but fully engaged. Scholars profess, "Mindfulness is as much about the quality of attention as it is about the conservation of attention. It is as much about what people do with what they notice as it is about the activity of noticing itself" (Weick et al., 1999: p. 90). "Heeding early warnings of trouble" is seen as a particularly important quality (Hoy et al., 2006). Indeed, much of the literature speaks to mindfulness as a capacity of consciousness, attention, being flexible, and having the ability to "break set" (Brown \& Ryan, 2003). The direction of attention stimulates deeper engagement with moment to moment experience. Brown and Cordon note that mindfulness promotes less reactivity to what has been before that yields an increase in efficiency during times of distress.

\section{Five Cognitive Process of Mindfulness}

Weick and colleagues offer one of the more developed models by identifying five cognitive processes that contribute to mindfulness in organizations: 1) preoccupation with failure, 2) reluctance to simplify, 3) sensitivity to operations, 4) commitment to resilience, and 5) deference to expertise. Preoccupation with failure is the signature component of an organization's culture that nurtures mindfulness. Vogus \& Welbourne (2003) claim this concern over emerging problems is a key indicator of a healthy organization. Failure is viewed as a condition for learning. Edmondson (2004) defines failure as the "deviation from expected and desired results, to include both avoidable errors and unavoidable negative outcomes of experiments or uncertain actions" (p. ii3). This broad definition of failure contains a number of key components. First failure is interpreted or limited to results that depart from the explicit purposes of an activity. Failure may include a lower rate of production than is desired (e.g., in schools this would include low student passing rates) as well as production of negative goods or services that are in addition to those desired (e.g., teacher burnout). The definition assumes that organizations are structured to exclude or regulate actions that are certain to produce negative results. Further, the reference to experimentation and uncertainty includes negative outcomes that are not due to error.

Reluctance to simplify refers to how people can be encouraged within organizations to seek out and maintain different viewpoints and maintain. People are naturally prone to interpret new information in ways to confirm their expectations. As a result this simplification can increase the potential for surprises (Weick et al., 1999). Knowing that anomalies can accumulate without recognizing the potential consequences, people who are skeptics can cultivate "conceptual slack". Conceptual slack arises through recognizing that there may be missing information. Skeptics are welcomed in this model as they tend to discourage complacency. Disagreements and divergent perspectives allow for the organization to adjust as members negotiate to yield action as information is shared.

Sensitivity to operations leads to paying attention to real time information. People need to distinguish what is current or fresh in terms of contextual data from what is old or has been given or assumed. Sensitivity to operations is largely about gaining and continuously updating "situational awareness" of individuals (Weick \& Sutcliffe, 2007). Situational awareness refers to a level of intensity and cognitive integration. Scholars agree that situational awareness allows for action to be taken as members notice more and make adjustments in complex environments (La Porte, 1996). It also results in staying "close to the core function of the organization" (Eck, 2011: p. 38).

In organizations, commitment to resilience is an ability to bounce back from errors, recover and continue with operations after mishaps. It is about coping in the moment when surprises arise by expanding knowledge and providing expert problem solving. Resilience is preparing for the inevitable by expanding technical expertise 
and taking command over whatever resources are available (Wildavsky, 1991). Weick \& Sutcliffe (2007) claim it is having the ability to absorb strain, recover, and learn and grow as the result of previous events. These scholars further discuss that resilient practices yield new learning, increase flexibility, and improve the experience repertoire within the organization. Weick and Sutcliffe further explain, "A commitment to resilience is difficult to sustain because you have to keep learning without knowing in advance just what you will be learning or how it will be applied" (p. 73). Patterns of resilient behaviors include real time learning where unexpected situations occur at a rapid rate, where there is an increase in wariness, and developing coping skills are an explicit part of training and professional development.

Lastly, deference to expertise refers to decisions migrating to those in the organization with the greatest expertise. Deferring to expertise allows for filtering information to all levels of the organization where those in lower ranks are expected to ask questions when unexpected problems occur. In examining the differentiation and integration of subsystems in complex organizations, scholars contend the environment in organizations is differentiated into distinct subsystems in order to achieve optimal performance within the organization (Lawrence \& Lorsch, 1967). Decisions can be dispersed to those with the greatest expertise since "Often when the correct decision is not known or the event is unfamiliar, the decision ratchets up the hierarchy, looking for the person who is ultimately accountable" (Roberts, Stout, \& Halpern, 1994: p. 620). The key is to link expertise on problems with decision making authority.

\section{Methods}

Herr \& Anderson (2005) define action research as "inquiry that is done by or with insiders to an organization or community, but never to or on them" (p. 3). Kurt Lewin has been credited with developing action research. He was not the first to hold or advocate for many of its principles, but given his reputation and support they became more acceptable and have been adopted by many of the social sciences. Lewin believed that if the social sciences were to benefit society they needed to advance knowledge that was practical and closely connected to real-life situations. Further, he wanted a way for professionals to continue learning and developing their understanding and effectiveness for coping successfully with problems.

\subsection{Procedures and Data Collection}

The goal of action research is to improve practice. Stringer (2007) argued, "Action research provides the means by which people in schools, business and community organizations; teachers; and health and human services may increase the effectiveness of the work in which they are engaged" (p. 1). To achieve such outcomes most projects that employ the design follow a cycle of inquiry involving plan-act-observe-reflect (Herr \& Anderson, 2005). Baskerville (1999) explained how the cycle is beneficial, "The fundamental contention of the action researcher is that complex social processes can be studied best by introducing changes into these processes and observe the effects of these changes" (p. 4). The cycle of inquiry thus presents a process that enables practitioners to identify the applicability of knowledge or practices and incorporate new insights into their work.

The lead author, Nancy, is the superintendent whose perspective is shared through narrated stories using critical events and everyday interactions that occurred during the two years of this study. The majority of data gathered for this study was through her observational field notes and reflective writing. Triangulating these data were material gathered from meeting minutes and other documents, reports, manuals, and artifacts related to the operation and governance of the district and were public documents. In addition, data were gathered by both Gordon and Teena who conducted interviews with Nancy, members of her leadership team, her board, building administrators and teachers, and parents. Interviews with Nancy involved debriefing her activities and reflecting on her practice. Interviews with other district participants focused on various aspects of the conceptual framework such as questions about their concerns or how particular problems or issues within the district were being handled and what was being noticed or going unattended by district leadership (e.g., preoccupation with failure and sensitivity to operations), what their contribution and responsibilities entailed and their voice in changes that were underway in the district (e.g., deference to expertise), what barriers to change had they noticed, adjustments made to prevent problems, and how they saw them overcome (e.g., sensitivity to operations and commitment to resilience). Both co-researchers also conducted observations shadowing Nancy as she went about her work and made field notes afterwards. 


\subsection{Researcher Positionality and Ethics}

Nancy invited Gordon and Teena to participate in the study given their expertise and prior relationship. Gordon had served as chair of Nancy's dissertation in which she examined her role as executive director in supporting the leadership of two principals and strengthened their practice using mindfulness. Prior to becoming superintendent, Nancy had served in the central office providing oversight for 21 schools and their building leadership. Teena had also recently changed roles from being a superintendent to becoming university faculty. Once members of the research team agreed to be involved in the study, a proposal was submitted to the Institutional Review Board (IRB) and was qualified as exempt. The proposed study was also shared with members of the TSD school board and received full endorsement. Since Nancy's role in the study and position in the district will be known, the participants were not promised confidentiality.

\subsection{Analysis}

Gathered data were coded for themes. All of the data were assembled into various incidences as they pertained to the five processes for mindfulness; preoccupation with failure, commitment to resilience, reluctance to simplify, sensitivity to operations, and deference to expertise. Trustworthiness of the findings is established by a rich description, prolonged engagement, and triangulation (Lincoln \& Guba, 1985) as well as Nancy's continued interest in engaging in the process of learning. Perhaps an unconventional notion of validity, Nancy's received evaluations speak to the merit of the project as well as her desire to continue serving as superintendent of the district.

\section{Findings}

\subsection{A New Superintendent in a Small Urban District}

The Tukwila School District (TSD) is located in a community of 20,000 people and shares the same name. It is a district located just south of Seattle. The community of Tukwila supports its schools as voters have consistently passed levies and bonds. Parents serve on school site councils and service organizations. This is a small district with students enrolled in five schools ( 3 elementary, 1 middle, and 1 high school). It is also one of the most diverse districts in the country, with approximately 80 languages spoken. TSD is home to several refugee centers and community based organizations that support immigrant families. Thirty-nine percent of students in the district qualify for English language learner (ELL) services and 78\% of students are eligible for free/reduced school meals. Ten percent of the students are homeless. The cost to transport homeless students has reached $\$ 350,000$ per year. The mobility rate of students has risen to $21 \%$ and the 4 year graduation rate of $53 \%$ has been trending downward. Schools in the district receive many students with interrupted formal education (SIFE) as well as varying levels of education from other places, and many high school students are new to the country. The district is a partner in a regional project funded by federal and private foundations aimed at improving the outcomes for students from "cradle to college." The goal of the project is to provide a unified effort with sharing of ideas and strategies to increase the achievement in this high poverty, high ELL region in the state.

\subsubsection{Instability in Personnel and Other Challenges}

TSD for multiple years has been deemed by the state's accountability system as a "failing" district and is "in improvement." With No Child Left Behind (NCLB) mandates and the loss of the waiver by the state, the middle school is in step 5 for Adequate Yearly Progress (AYP) and has been identified as being in improvement specifically in the areas of ELL and special education. The remaining four schools are also in various stages of improvement from step 2 to step 4 of not making AYP. Yet, across the district there has been too little effort directed at reversing course and much that appears aimed at keeping things the same. For example, the instructional performance reviews of faculty in previous years rated classroom teaching as satisfactory using a binary system for the majority of the staff and unsatisfactory for very few staff. Prior to Nancy's hiring in 2012, evaluation processes identified no teacher as needing corrective action and no evidence of faculty being placed on probation.

Perhaps some of the difficulty conducting meaningful personnel evaluation was attributable to significant turnover in leadership with eight assistant superintendents in nine years and three superintendents in six years. The revolving door at the building level, however, was limited to the high school, with nine principals being appointed to the position over the last ten years. Interestingly, principals at three of the elementary schools and 
the middle school remained stable over the same ten year period. With such change, a "this too shall pass" mentality had been nurtured, which was how Nancy came to perceive the push-back from some personnel on the initiatives she supported after assuming the superintendency. During her interview for the position, the TSD school board made it clear that she was being hired to adjust course. They wanted a superintendent who would reform the district's culture, improve instruction in every classroom, and increase positive learning outcomes for students.

Although the district is considered failing, it has thus far avoided being designated for turnaround. And yet it has been highly impacted by turnover in its central office prior to and after Nancy's acceptance of the offer of superintendent. One of the other candidates for the position was a district insider. In extending the contract to Nancy, the board had signaled its opinion on previous leadership which resulted in the voluntary resignation for employment elsewhere of one cabinet member within the first few months of Nancy's hire. More resignations soon followed. In her first 18 months in the district, Nancy had to hire replacements for her Director of Special Education, the Director of ELL, and the Executive Director of Business and Finance, and three times her Director of Human Resources. She also hired an interim Assistant Superintendent followed by the current Assistant Superintendent and new administrators for the high school. Nancy's predecessor had demoted one administrator at the high school to a classroom teacher as this administrator had neither conducted observations nor written evaluations for his staff right before Nancy had been hired. The staff had actually filed a grievance against all three administrators of the high school for not having been observed the legal number of times.

Compounding the challenge to address needed improvements in instruction without appropriate evaluation procedures in place, while securing an almost completely new leadership team and getting new members up-to-speed, was the lack of a district strategic plan, as well as an inherited discrimination lawsuit. Nancy had known about the lawsuit when she applied for the position. It was not long after accepting the position, however that she began experiencing sleeplessness, worrying how she would lead the district and manage its resources to secure what students needed given the award for damages that she could see would take a heavy toll on an already tight budget. Litigation consumed many of her days, even weeks, as the process came to a close near the end of her first year. The plaintiffs were current and former African American employees and the key defendant was the former superintendent. The school board had accepted the resignation of the former superintendent and wrote a statement explaining it had found no evidence to justify the alleged complaints of racial discrimination. After becoming involved, it became clear to Nancy that these employees had not been treated fairly or with dignity. In consultation with her legal counsel and risk management, the district decided to mediate out of court.

The lasses-faire attitude toward personnel evaluation that was evident in the disconnect between student assessments and reviews of educator performance, as well as other weaknesses in operational norms related to curriculum and instruction, became increasingly the focus of Nancy's concern as she got to know the district better. She hired outside auditors that first fall to dive into every director's business in order to get a fair assessment how each department was doing. The audits found multiple issues within each unit. Perhaps most egregious in number were the 45 findings in the special education department. Several directors elected to resign given the outcome of these audits, while a few others took their time to recognize that change was underway. The audit findings became Nancy's justification to explain what and why modifications were needed for taking corrective action. In tandem with this effort, a consultant had been hired to help prepare Nancy and her cabinet, and later walk the staff through the process of creating a strategic plan. The plan that was designed to reinforce and clarify the instructional focus in the district on teaching, leading, and organizational practices was based on 4 pillars: equitable access to standards aligned instruction; caring effective teachers, leaders and staff; supportive climate and strong relationships with families and communities; and results focused data-driven continuous improvement.

\subsubsection{Feeling the Cost and Recognizing the Reward}

The previous description of the district highlighted key events in Nancy's first year and provided some insight into the challenges that she would confront her second year to address some of the sources of TSD's failing status. The difficulties Nancy experienced are easily appreciated as stressful. Nancy seriously considered quitting. Her personal relationships were suffering. She had gained weight. Her doctors had prescribed medication to help reduce her high blood pressure and decrease her heart palpitations related to anxiety. Long hours every day, for month after month, contributed to her exhaustion and nagged doubts about what she was accomplishing. There were times when she felt alone, but rather than feeding or allowing those thoughts to run free she would stop 
herself. And she drew on the encouragement from others to keep moving. She replenished her commitment to resilience through her interactions with students, her families, faculty, and staff.

For example, Nancy had received a letter from a high school student, which resulted from one of her regularly scheduled instructional rounds. The student wrote, "You ma' am I say are a very interesting individual. You are unique in your own way; both inspiring and fascinating. Regard this as a letter from a friend, from a student that deeply cares. Below I explain a few particulars about me and some things that I closely hold to heart". He went on to offer just that and then explained,

I recall it being a Tuesday, I was in Spanish 1. That day, I sat in the very back of the classroom... you walked in and established your presence. You stood in direct contrast to many. And unlike the handful of visitors I have seen, you actually talked to students, and carried out actual conversations. You were not an imposing figure who spoke with a certain degree of authority, and your questions definitely did not begin with, "what are you supposed to be doing right now?" ... Then, before the dismissal bell rang you walked towards me. I greeted you and you likewise, and from there it all began. Right when I uttered my name, Hassan, you asked me what grade I was in, 10, and then asked whether or not I enjoyed Spanish, and "yes, I do enjoy learning foreign tongues," I replied a bit reserved. Your last question, however, startled me-not because of familiarity, for I had much of that, but by its far-reaching implications. I want to say thank you, Dr. Coogan, for giving me one of the most meaningful forty seconds of my life. Hopefully, one day, I will figure what I want to do with my life.

He continued to plead with her as superintendent, that she

widen the discourse and allow students like myself to have a say as to how our school functions. Do you seriously have to be on student government, which I am not, or leadership for your voice to be heard? Does our voice not matter, at least for those of us that are not part of leadership or student government? Let us as students have a dialogue, and build understanding, and make our school a better place. Include us, offer us opportunities, because we too want to help. I ask of you as our superintendent to advocate for our ELL students and keep in place such vital programs. And I know you have our school's best interest in mind. It is evident in the manner you speak, and the things you do, that you deeply do care about us.

Nancy considered her both instructional rounds and school visits (i.e., meeting students during lunch, greeting with parents at events, etc.) critical for listening to how others were making sense of the direction the district was heading. Her instructional rounds kept her attuned and sensitive to how the district's schools were operating.

\subsection{Closing in on an Instructional Framework}

It was not long after assuming the position that Nancy determined that there was no cohesive pre K-12th grade curriculum or shared teaching philosophy to guide or support the work of her teachers. There was a distinct need to develop an instructional framework. Keeping instructional related problems from getting bigger while making her assessment of the human resources in the district for undertaking this task had been Nancy's anticipatory steps during the first year. During her second year, she not only worked at establishing evaluation and teaching norms but formed a committee that she hoped would build the instructional framework and outline professional development for upcoming years. It should be mentioned that without such agreements, Nancy and her leadership team encountered a number of problems addressing issues of poor teacher performance noted previously. The framework was also necessary to provide a way to align and infuse various components of the district with a literacy focus. It was to be an instructionally oriented model that would specifically present information and process for integrating literacy instruction with the common core state standards and the next generation science standards across all content areas.

Nancy began to identify the members of the committee through conversations with her cabinet as well as other administrators and teachers as she visited buildings. Her idea was to get various participants from across the schools to create a framework that would be viable and therefore needed to tap into different areas of expertise possessed by TSD faculty and staff. Such a tactic was thought to nurture their willingness or agreement to change their practice. Nancy drew on those identified with expertise and supported them in gathering literature, attending conferences, and sharing their understanding of literacy research and best practice.

A number of components that make the instructional framework that was developed emerged from a subcommittee that broke off from the larger group charged with the task. The subcommittee was made up of instructional coaches, teachers, and Nancy. Nobody from teaching and learning unit in the central office volunteered or attended any of the subcommittee meetings. Nancy assumed their lack of participation was due to trust 
in those at the table. Most of the members of the subcommittee had gravitated to Nancy. The purpose in forming the smaller workgroup was to move specific tasks forward as the larger committee felt they had taken the structure and guidelines as far as they could. This smaller committee put in hours and produced the details that followed the earlier articulated framework, but added a 3- - 5-year professional development calendar to facilitate enriching teacher knowledge and capacity for instructional leadership. The subcommittee also identified the "must dos" for all teachers combined with various hybrid professional development models.

When the final meeting was scheduled with all of the principals and all directors of teaching and learning to examine the subcommittee's proposal, members of the subcommittee were nervous. Nancy was also apprehensive as her high school administrators were known for being cautious and perceiving their faculty as reluctant to change. Nancy had heard on more than one occasion that teachers in the high school had never even looked at data, that teachers were not used to having or being focused on instruction, and that prior to the new team of administrators there had been no structures in place to evaluate teaching. In reflecting back on the hours upon hours of release time provided for teachers and coaches to do this work, Nancy wondered if maybe she should have mandated representation from her administrators. There were, however, three high school teachers on the subcommittee. Nancy elected to strategically launch the presentation with her association partner (i.e., the incoming union president). She began by explaining how they had collaborated on this project and that they had been looking for a different structure for carrying out professional development. For multiple years the district had operated with late start Wednesdays during full weeks of school, but not during partial weeks of school. The model did not make a lot of sense, other than the idea that during shortened weeks teachers would have less time to attend to professional development needs. The schedule was not determined by teacher learning needs per se but perception of their workload. Consulting with teachers and association partners, it was agreed that "SMART" Wednesdays were not that smart. Teachers were receiving a "shot in the arm" professional development with no time for application or analysis of the professional development. It was also extremely disjointed with no long term vision of how the learning fit into the bigger picture of the strategic plan and or CCSS or NGSS. Finally, refugee/immigrant families did not understand what "late start" meant despite robo calls in multiple languages almost weekly. Children were continuing to arrive each day at the same time. The district needed to operate with predictability and consistency for its families.

The union president "to be" stated that this was a great partnership and she was excited about the opportunities that were coming out of this subcommittee and the commitment from the district to make this right with solid, job embedded professional development that was aligned with the strategic plan. Next to speak at the meeting were representatives from the elementary, middle, and high schools. They explained the rationale behind the work, the objectives, and the potential opportunities. The committee shared the differentiated professional development model beginning with what is essential for everyone to "have to" do (that had required release time and/or SMART Wednesdays) followed by less essential professional development which would occur after school hours and/or "professional development in your jammies" (i.e., a virtual meeting on Saturday mornings supported through online resources). The committee had blown up the SMART Wednesday structure to combine all "time" used throughout the year into longer blocks for teacher professional development.

There were times built into the presentation for reflection and for the leadership team to stop and jot. When presenting the professional development plan, the strategy referred to as "bless, press, and address" was employed. Each person was required to write on a sticky note what they "bless" which was interpreted as a strength in the plan. They then wrote a "press" that is a genuine wondering about the plan, and concluded with an "address" to identify something to consider, not a necessary change. At the end or presenting all aspects of the plan, each person had to report out on what they liked about the plan and what they were still grappling with. The high school administrators never acknowledged that the district was going in the right direction, and instead began by complaining about how various central office administrators had interfered with their professional learning communities. A part of Nancy wanted to chime in, but she chose remain silent. When it came to one of the high school language arts teachers to speak, she had been a member of the subgroup, she started to cry. She said she was excited about the work and how it honored the current work of the high school. The high school principal then cried and thanked the teacher for participating on the committee. It was an interesting moment for Nancy, as throughout the framework meetings she gave emphasis to the importance of honoring what was accomplished in all buildings. Nancy started to tear up, partly because she was tired but also her realization about the fruits of the labor of better than a hundred hours.

The leadership team had many questions and comments at the end, but Nancy was confident that implementa- 
tion of the instructional framework district wide would soon begin. The next steps will center on delivering the message to all buildings at staff meetings. Over the next few months Nancy acted strategically to deliver her message and continue solidifying implementation of the framework. She worked with her leadership team to identify professional development release days, change the delivery model of SMART Wednesdays to include $1 / 2$ day releases, and negotiated contracts for substitutes for the days they would be needed. The district will be paying substitutes more than they would get, but by signing the contract they guarantee that they will be available. Nancy is in conversations about the potential of adding benefits to substitute contracts who give 25 guaranteed days or more as an outgrowth of these efforts.

The committee that developed the framework helped to disseminate and build identification among district personnel that improvement in literacy based strategies was paramount to increasing the achievement of all students. Since the district is in improvement, the adopted framework also addresses the requirement imposed by the state to provide supports for schools needing additional assistance. Teachers and administrators have "look fors" to promote literacy across all contents. The "look for" document also assists struggling teachers as it identifies the kinds of practices teachers should be doing as well as ways to better engage students in their learning. The activities and conversations that were part of creating the framework tested it for utility using a number of struggling teachers. For some, using the principles and strategies of the framework began a process of improvement while others continued to struggle. Nancy non renewed a couple teachers at the end of her second year given the seriousness of their problems and a few resigned with dignity.

\subsection{Making a Good Hire}

Hiring an entire cabinet is a rare experience for any superintendent. Since turnaround policy requires replacing people, we offer this description to delve deeper into the ways mindfulness was evident in these tasks and how we came to reflect on the manner in which the cognitive processes supported Nancy in leading the district. Before sharing, we wish to point out that this was Nancy's last hire for her leadership team and she had come to possess clarity and focus on how she attended to the five cognitive processes in her work.

After the first year, Nancy recognized her need to work more effectively. Her assistant, while capable, desired to work in the high school to "make a difference," as well as not having the long and odd hours needed to support the superintendent. When an appropriate position was posted at the building level, Nancy advocated for her assistant. With the opening pending, Nancy asked her previous assistant Maria, if she would be interested in working with Nancy again. In Nancy's mind, Maria's grace and charm made her a natural fit for the district. Maria agreed and submitted her materials.

During Maria's interview, Nancy was humbled when Maria stated to the committee that she had been in employed in the largest district in the state for 15 years and "had many, many bosses," but felt that it had been a rare opportunity to work for Nancy, as she was someone who Maria felt had shared her values. Nancy recognized in that moment that she had reached out to someone she knew was about being in service to children. Maria shared a little about her work with ex addicts who come out of rehabilitation. She spoke without casting judgment, or blame, simply that it was her goal to help others become well again. She explained that she worked out with them, ran with them, and trained with them on various goals including climbing Mount Rainier. She explained how this built character and trust. She informed the committee that some of the addicts she worked with lived in Tukwila. She requested that she be allowed to leave work early on Thursdays in order to train with these mothers and their children. Nancy was not surprised by her request, as Maria's core values match her own.

Now that Maria works in the district, her kindheartedness is well known. In one instance, a teacher at the high school shared with Nancy that she was looking for a running partner. Nancy brought Maria to the teacher's civics class to introduce them and as they walked into the classroom, students were sprawled out on the floor, at desks, working independently on their projects. Andrea, the teacher, was thrilled to meet Maria and they appeared to connect on many levels. They made plans to meet and begin training. What surprised Nancy was hearing a student on the floor ask, "Maria, are we on for Thursday?" Maria immediately dropped to the student's level and said "Yes, we will work out prior to running this week." When they left Nancy asked her who the student was. Maria informed Nancy that the student was the daughter of one of the addicts she was training with.

Maria works tirelessly. She is committed to the mission of the district. She buffers calls from curmudgeons, deals with irate parents, and navigates many challenges, always doing such with a smile, attending to conversations, and a firm handshake that exudes confidence. Recently, the NAACP was invited to the district, by them- 
selves and Nancy's Assistant Superintendent, to conduct an investigation of how the district treated its African American students and employees. Their attention is a lingering fact of the previous lawsuit and inappropriate actions on the part of past administrators as well as being concerned with poor performing schools that has had the same leadership for more than a decade. The report that followed their brief visit of schools and with the board, focused on questions about hiring practices and services being provided for students of color. Additionally anonymous letters were sent to the school board where employees were unhappy with district leadership. Maria read the letters and commented to Nancy, "That's interesting reading". Rather than getting caught up in the drama, Maria returned to her work by asking Nancy how she could help. Maria does the simplest things such as attending a basketball free throw tour, sponsoring students, or assisting with finding supplies for students. Some of these may seem like little things, but they are important when they are added up.

\subsection{Arranging a Funeral}

December 8th Nancy received a call about a tragedy that turned Tukwila School District upside down. The mother of six children had passed out in the kitchen of their apartment. She was 6 months pregnant with her seventh child. 911 was called, but the pregnant mother died in route to the hospital and a C-section was performed to save the $2.5 \mathrm{lb}$. baby girl. Two of the children attended Mountain View Elementary School, two went to Lincoln Middle School and two were King High School students. The oldest, a senior, was the first of her family on target for graduating with a diploma in June. Nancy went to the apartment complex with the Director of ELL only to find the Burmese community rallying around the family. Shoes lined the door outside the apartment. As Nancy entered the small apartment she was greeted with a hug by several family and community members. Many children were sitting in the middle of the rug with their mothers, each looked shocked and in disbelief. Pictures of Jesus were hung on the wall and some Christmas lights had been strung. Nancy thought she was there to provide some support, but she did not recognize the magnitude of what was needed nor the outcome that would follow.

The apartment appeared dirty with little place for sitting. One of the students, sobbing and sharing pictures of her mother, sat next to the high school counselor who had come separately. The girl was sharing a picture of her newborn sister in ICU, barely surviving with tubes and monitors galore. The pastor was explaining the family had no money for the burial. The school's Burmese interpreter was there also and translated what the pastor was saying about the funeral service costs, which started around $\$ 18,000$, as well as additional expenses of the casket, flowers, and other incidentals that needed to be purchased. The family was without a plot too. Nancy listened as the pastor asked her directly for help.

After leaving the apartment, Nancy called her communications director about the situation as she drove over to the high school for a previously arranged meeting. Her director acted and set up a website for people to make donations. The local media heard the story and broadcasted it and the website for multiple days.

After returning to her office, she called a local funeral parlor and spoke with Mark, who was its director. She found him easy to speak with. His calm demeanor made her feel at ease and she began to tear as she explained the tragedy in all of its detail. He simply responded, "We will do whatever we can to assist." Nancy was not sure what he meant, except his poise made her feel that it was going to be okay. Later he would call and ask her to bring the family in. The parlor, he told her, would pay for the funeral and he was working on securing the plot. It took few days, but he found a woman who donated her plot as she no longer lived in the area.

As the date of the funeral approached, Nancy continued to seek further assistance that had been requested by the family during that initial home visit and subsequent follow-ups. It was Nancy who called the father's employer to request that he be allowed to return after the New Year and his need for day shifts versus swing shifts so he could take care of the children. She was answered, "Yes, of course. Please let him know we are giving him four weeks of pay while he is out and he will not have to take any vacation days." They too had started a collection on behalf of the family. Nancy was regularly approached with offers of assistance as she went about her work. The mother of a staff member came forward to become a Secret Santa for the six children for Christmas. A local daycare was found to take care of the baby. This was of particular importance as Nancy wanted the high school senior to remain in school. Nancy feared even though the girl was so close to graduating that she would dropout to take care of her younger siblings. A community member was found to walk the children to and from school. This does not mean that all went smoothly. For example, once the landlord of the building found out there were more than 4 children in the apartment due to the media hype, the family was asked to find another 
place to live. The family had reported 4 children since they could not find housing for 6 children when they had first arrived. And then the hospital would not release the body for over a week and there were a number of initial difficulties with securing a death certificate.

The day of the funeral was quite trying. The chapel was full with standing room only. The service was in both Burmese and a little bit of English. The family requested that Nancy speak on behalf of the school district. The person introducing Nancy embarrassed her with his kind words. She felt humbled. She stopped at the open casket, genuflected, and went to the podium with an interpreter by her side. She shared a brief story, affirmed love for this family, and pledged commitment to their success. After the music, the eulogy, the words of hope in Burmese, the entire Burmese community walked up the hillside on foot behind the chapel where the body was laid to rest.

The website that had been set up that first day collected over $\$ 60,000$ which was moved into a trust that will be administered by a local charity on behalf of the family. The state department of social and health services became aware of their situation and has provided services. The district is now focused on keeping a close watch on the family and providing wrap around services for these children.

One of the unintended outcomes and lingering issue to emerge from Nancy's home visit was a recent discussion she had with the former mayor, and current board member, to determine what to do about the infestation of bedbugs in the apartments of families with students who attend TSD. Nancy had noticed welts on the arms and legs of the Burmese community liaison after their visit. She was informed that some of her families have to sleep in the middle of the living room sitting up, back to back, and they can visually see the bedbugs coming out from behind the molding when its dark. Nancy determined that something needed to be done and asked her board member, the former mayor, for guidance. He informed her that she would have to ask to have the city ordinances changed to allow inspectors to enter apartments since currently the housing authority cannot require access to all apartments. Nancy worried about naming the apartments for fear that the slumlords would kick out these families for letting people know about the intolerable living conditions.

Armed with the information, Nancy intended on attending the city council meeting to express her concern during public testimony. She could not attend due to illness. Representing her at the meeting was the district's family liaisons (Burmese, Nepali, Somali, and Latino) and Family Engagement Coordinator. The city council asked questions and her team reported to Nancy their positive reception. A week later, however, Nancy attended her monthly visit with the coordinator from the mayor's office. Here she was scolded. The coordinator from the city informed her that the mayor should have received a "heads up." Nancy stood her ground and informed him that she had acted in good faith. She felt she had followed appropriate channels and that she had discussed the situation with the former mayor who had gone to the housing inspector to let her know of the significance of this problem. From Nancy's perspective it appeared as if voicing concerns was not being viewed as a "call to action" and that to sit by and do nothing was no longer acceptable. Nancy was concerned that when families vocalized such problems they were being evicted and that needed to stop.

Nancy never imagined all the problems that would come to her. And there are concerns that have been raised to Nancy about her involvement. She has been asked "What about other families? When they have challenges are you going to be there to support everyone?" Her answer is firm and patient. All families are important: I am here, we are here for everyone.

\section{Discussion and Conclusion}

Nationally, the average tenure for urban superintendents is three years (Wills, 2014). This examination of events and efforts involving one superintendent's experience and from her perspective offers meaningful insight into the increasingly complex role and responsibilities placed on those occupying this most visible and critical position. The pressures from within and without the organization were significant and turnover in district personnel could be seen as both assisting and impeding Nancy's leadership for change. Scholars call for description to better understand the turnaround experience in order to develop sound recommendations for leadership practice and revisions to educational policy (Malen \& Rice, 2004; Murphy, 2009). Through our description and analysis we have attempted to show that the skill and energy involved in responding to various demands that arise from the instability in district personnel, in addition to that which is required by normal education operations, are no small feat. Indeed, perhaps one of the main inferences we offer from listening, observing, and reflecting on leading a turnaround process at the district level is the importance of recognizing the difference between an appropriate 
response and a reactive reaction.

Interaction that was responsive rather than reactive tended to be grounded or manifested one or more of the cognitive processes of mindfulness. Nancy spent much time in visiting her schools and creating relationships with members of her district to better hear and understand what students were learning (i.e., sensitivity to operations). Observing teachers in classrooms, talking to students, hiring auditors, visiting with parents, and being accessible were critical tasks in noticing problems and clarifying issues (i.e., preoccupation with failure). When mistakes and difficulties were brought to her, she attempted to provide adults, and children especially, with second, third, and even fourth chances to correct behaviors but each time improved supports and documentation (i.e., reluctance to simplify). Deference to expertise was a key strategy that was evident in gathering together selected members of her faculty and staff to work on committees and projects as well as when she sought input and channeled information, and gave decision making to others. Nancy strengthened her commitment for resilience through multiple means, including undertaking this study. She kept her belief alive that the decisions she had made were adequate by reaching out and giving heed to feedback she received from those she served. Through being responsive in these ways, Nancy sought to balance the multiple and conflicting demands that surfaced as she endeavored to lead her district in a new direction. While the particulars of the incidents shared may be unique, we suspect that the general nature of the challenges and responsibilities in turnaround leadership are not, including most notability: building relationships with the school board, district staff, and community; hiring and firing of cabinet members, building level administrators, and teachers; revamping instructional and evaluation practices, while seeking to build trust with stakeholders; and bringing predictability and voice in district governance.

The research process of attending to the five cognitive processes of mindfulness, which were evident throughout the described incidents, nurtured Nancy's resilience. Being intentional about what she was giving attention opened her ability to notice more, avoid complacency, be patient with dissension, and believe in the expertise of those in the trenches to do their work. Mindfulness in these ways strengthened Nancy's coping with the stress of leading a district defined as in improvement and one that experienced much turnover in its administrative leadership. Turning around a district embroiled in conflict, lacking institutional memory, where arbitrary enactment of dated policies and procedures has been accepted practice, requires listening to your inner voice, developing a trusting team, and having courageous conversations. High stakes accountability may be a tool for changes, but it is mindfully serving children and families that nurtures resilience.

\section{References}

Aud, S., Hussar, W., Kena, G., Bianco, K., Frohlich, L., Kemp, J., \& Tahan, K. (2011). The Condition of Education 2011 (NCES 2011-033). U.S. Department of Education, National Center for Education Statistics. Washington, DC: U.S. Government Printing Office.

Baskerville, R. L. (1999). Investigating Information Systems with Action Research. Communications of the Association for Information Systems, 2, 1-32.

Bellingrath, S., Weigl, T., \& Kudielka, B. (2009). Chronic Work Stress and Exhaustion Is Associated with Higher Allostastic Load in Female Teachers. Stress, 12, 37-48. http://dx.doi.org/10.1080/10253890802042041

Berkovich, I., \& Eyai, O. (2015). Educational Leaders and Emotions: An International Review of Empirical Evidence 1992-2012. Review of Educational Research, 85, 129-167. http://dx.doi.org/10.3102/0034654314550046

Brown, W. K., \& Ryan, R. M. (2003). The Benefits of Being Present: Mindfulness and Its Role in Psychological Well-Being. Journal of Personality and Social Psychology, 84, 822-848. http://dx.doi.org/10.1037/0022-3514.84.4.822

Burpee, L. C., \& Langer, E. J. (2005). Mindfulness and Marital Satisfaction. Journal of Adult Development, 12, 43-51. http://dx.doi.org/10.1007/s10804-005-1281-6

Carson, S. H., \& Langer, E. J. (2006) Mindfulness and Self-Acceptance. Journal of Rational-Emotive \& Cognitive-Behavior Therapy, 24, 29-43. http://dx.doi.org/10.1007/s10942-006-0022-5

Conley, S., \& You, S. (2009). Teacher Role Stress, Satisfaction, Commitment, and Intentions to Leave: A Structural Model. Psychological Reports, 105, 771-786. http://dx.doi.org/10.2466/PR0.105.3.771-786

Eck, J. (2011). Best in the World: High Performance with High Reliability. In J. Eck, S. Stringfield, D. Reynolds, E. Schaffer, \& G. Bellamy (Eds.), Noteworthy Perspectives: High Reliability Organizations in Education (pp. 36-44). Denver, CO: McREL.

Edmondson, A. (2004). Learning from Failure in Health Care: Frequent Opportunities, Pervasive Barriers. Quality and Safe- 
ty in Health Care, 13, 3-9. http://dx.doi.org/10.1136/qshc.2003.009597

Gardiner, M., \& Enomoto, E (2006). Urban School Principals and Their Role as Multicultural Leaders. Urban Education, 41, 560-584. http://dx.doi.org/10.1177/0042085906294504

Glass, T., \& Franceschini, L. (2007). The State of the American School Superintendency: A Mid-Decade Study. Arlington, VA: Rowman \& Littlefield.

Hawk, N., \& Martin, B. (2011). Understanding and Reducing Stress in the Superintendency. Educational Management Administration \& Leadership, 39, 364-389. http://dx.doi.org/10.1177/1741143210394000

Herr, K., \& Anderson, G. L. (2005). The Action Research Dissertation. Thousand Oaks, CA: Sage Publications.

Hoy, W., Gage, C., \& Tarter, J. (2006). School Mindfulness and Faculty Trust: Necessary Conditions for Each Other? Educational Administration Quarterly, 42, 236-255. http://dx.doi.org/10.1177/0013161X04273844

Kendra, J. M., \& Wachtendorf, T. (2003). Elements of Resilience after the World Trade Center Disaster: Reconstituting New York City's Emergency Operations Centre. Disasters, 21, 37-53. http://dx.doi.org/10.1111/1467-7717.00218

Klusmann, U., Kunter, M., Trautwein, U., Ludtke, O., \& Baumert, J. (2008). Teachers' Occupational Well-Being and Quality of Instruction: The Important Role of Self-Regulatory Patterns. Journal of Educational Psychology, 100, 702-715. http://dx.doi.org/10.1037/0022-0663.100.3.702

Kutash, J., Nico, E., Gorin, E., Rahmatullah, S., \& Tallant, K. (2010). The School Turnaround Fieldguide. San Francisco, CA: FSG Social Impact Advisors.

La Porte, T. R. (1996). Hight Reliability Organizations: Unlikely, Demanding and at Risk. Journal of Contingencies and Crisis Management, 4, 60-71.

Langer, E. J. (1993). A Mindful Education. Educational Psychologist, 28, 43-50. http://dx.doi.org/10.1207/s15326985ep2801_4

Lawrence, P. R., \& Lorsch, J. W. (1967). Differentiation and Integration in Complex Organizations. Administrative Science Quarterly, 12, 1-47. http://dx.doi.org/10.2307/2391211

Lincoln, Y., \& Guba, E. (1985). Naturalistic Inquiry. Beverly Hills, CA: Sage.

Malen, B., \& Rice, J. (2004). A Framework for Assessing the Impact of Education Reforms on School Capacity: Insights from High-Stakes Accountability Initiatives. Educational Policy, 18, 631-660. http://dx.doi.org/10.1177/0895904804268901

Messersmith, J., Lee, J., Guthrie, J., \& Ji, Y. (2014). Turnover at the Top: Executive Team Departures and Firm Performance. Organization Science, 25, 776-793. http://dx.doi.org/10.1287/orsc.2013.0864

Murphy, J. (2009). Turning around Failing Schools: Policy Insights from the Corporate, Government, and Nonprofit Sectors. Educational Policy, 23, 796-830. http://dx.doi.org/10.1177/0895904808320677

Murphy, J., \& Meyers, C. (2009). Rebuilding Organizational Capacity in Turnaround Schools. Educational Management Administration \& Leadership, 37, 9-27. http://dx.doi.org/10.1177/1741143208098162

Philipp, A., \& Schupback, K. (2010). Longitudinal Effects of Emotional Labour on Emotional Exhaustion and Dedication of Teachers. Journal of Occupational Health Psychology, 15, 494-504. http://dx.doi.org/10.1037/a0021046

Price, H. E. (2010). Does No Child Left behind Really Capture School Quality? Evidence from an Urban School District. Educational Policy, 24, 779-814. http://dx.doi.org/10.1177/0895904810376564

Ravitch, D. (2010). The Death and Life of the Great American School System. New York: Basic Books.

Rees, C., Breen, L., Cusack, L., \& Hegney, D. (2015). Understanding Individual Resilience in the Workplace: The International Collaboration of Workforce Resilience Model. Frontiers in Psychology, 6, 1-7. http://dx.doi.org/10.3389/fpsyg.2015.00073

Riehl, C. (2000). The Principal's Role in Creating Inclusive Schools for Diverse Students: A Review of Normative, Empirical, and Critical Literature on the Practice of Educational Administration. Review of Educational Research, 70, 55-81. http://dx.doi.org/10.3102/00346543070001055

Roberts, K., Stout, S., \& Halpern, J. (1994). Decision Dynamics in Two High Reliability Military Organizations. Management Science, 40, 614-424. http://dx.doi.org/10.1287/mnsc.40.5.614

Rodriquez, M. A., Murakami-Ramalho, E., \& Ruff, W. G. (2009). Leading with Heart: Urban Elementary Principals as Advocates for Students. Educational Considerations, 36, 8-13.

Sherman, W. (2007). No Child Left Behind: A Legislative Catalyst for Superintendent Action to Eliminate Test-Score Gaps. Educational Policy, 22, 675-704. http://dx.doi.org/10.1177/0895904807307063

Sicoly, F. (2002). What Do School-Level Scores from Larger-Scale Assessments Really Measure? Education Measurement: Issues and Practice, 21, 17-26. http://dx.doi.org/10.1111/j.1745-3992.2002.tb00103.x

Stringer, E. T. (2007). Action Research (3rd ed.). Thousand Oaks, CA: Sage Publications. 
Theoharis, G. (2008). Woven Deeply: Identity and Leadership of Urban Social Justice Principals. Education and Urban Society, 41, 3-25. http://dx.doi.org/10.1177/0013124508321372

Vogus, T., \& Welbourne, T. (2003). Structuring for High Reliability: HR Practices and Mindful Processes in ReliabilitySeeking Organizations. Journal of Organizational Behavior, 24, 877-903. http://dx.doi.org/10.1002/job.221

Weick, K., \& Sutcliffe, K. (2007). Managing the Unexpected (2nd ed.). San Francisco, CA: John Wiley \& Sons.

Wildavsky, A. (1991). Searching for Safety. New Brunswick: Transaction Books.

Wills, M. (2014). Average Urban School Superintendent Tenure Decreases, Survey Shows. Education Week. http://blogs.edweek.org/edweek/District_Dossier/2014/11/urban_school_superintendent te.html

Windle, G., Bennett, K., \& Noyes, J. (2011). A Methodological Review of Resilience Measurement Scales. Health and Quality of Life Outcomes, 9, 1-18. http://dx.doi.org/10.1186/1477-7525-9-8

Woods, S. (2009). Training Professionals in Mindfulness: The Heart of Teaching. In F. Didonna (Ed.). Clinical Handbook of Mindfulness (pp. 463-475). New York: Springer. http://dx.doi.org/10.1007/978-0-387-09593-6 26 